www.jmscr.igmpublication.org

Impact Factor (SJIF): 6.379

Index Copernicus Value: 71.58

ISSN (e)-2347-176x ISSN (p) 2455-0450

crossref DOI: https://dx.doi.org/10.18535/jmscr/v6i6.113

Journal Of Medical Science And Clinical Research

\title{
Haemodynamic changes with lower dose of Hyperbaric Bupivacaine with Dexmeditomedine and Conventional dose of Hyperbaric Bupivacaine for Subarachnoid Block in Lower Limb Surgeries (Orthopaedic Cases)
}

\author{
Authors
}

\section{Dr Ajith Kumar G*, Dr Geethakumari. P, Dr R.S. Ushadevi}

Dept. of Anesthesiology, Medical College, Trivandrum, Kerala, India

*Corresponding Author

Dr Ajith Kumar G

Dept of Anesthesiology, Govt. Medical College, Trivandrum, Kerala- 695011, India

Email: drajithkumarg@gmail.com

\begin{abstract}
Background and Aims: It is universally agreed that the anaesthesia of choice for lower limb surgeries is a subarachnoid block and a sensory level of $T-10$ is recommended to provide excellent anaesthesia for the patient. It is well established that opioids has got a prominent analgesic action at the spinal cord level and it can be used safely for subarachnoid block. If you can add a $\alpha$-2 adrenoreceptor agonist like Dexmeditomedine to hyperbaric bupivacaine (the standard drug used for sub arachnoid block) and thus reduce the dose of bupivacaine used, without compromising on the analgesic effect and haemodynamic changes.

Aim of the study: Primary aim: To measure the Haemodynamic changes like Blood Pressure and Pulse rateby adding dexmeditomedine to lower dose Hyperbaric bupivacaineand Hyperbaric bupivacaine alone. Secondary aim: Compare the side effects like nausea, vomiting, sedation, shivering and pruritis.

Methods: This study was prospective, randomized, comparative study double blind in nature and conducted after obtaining institutional Ethics Committee approval and written informed consent. The person giving the drug and the monitoring personnel were blinded 60 adult patients of ASA grade I and II aged between 20 - 50 year. Undergoing various elective lower limb (Orthopaedics) surgeries.

Results: Dexmeditomedine in a dose of $5 \mu \mathrm{g}$ was used for supplementation spinal Bupivacaine, showed that Haemodynamic changes like blood pressure and pulse rate is more on the bupivacaine group than dexmeditomedine group.

Conclusion: $5 \mu \mathrm{g}$ Dexmeditomedineto $2 c \mathrm{c}$ of hyperbaric Bupivacaine $0.5 \%$ is associated with lessor incidence of Hypotension and less Bradycardia compare to bupivacaine group had more incidence of hypotension and bradycardia.

Keywords: Dexmeditomedine, Hyperbaric Bupivacaine, Spinal anaesthesia.
\end{abstract}

\section{Introduction}

Dexmeditomedine is an $\alpha-2$ adreno receptor agonist, which is approved as an intravenous sedative and analgesic drug. It is useful adjuvant in regional anesthesia. Kanazi et al, found that $5 \mu \mathrm{g}$ clonidine are equipotent intrathecally when added to Bupivacaine in patients undergoing major surgeries in the abdomen and lower 
extremeties. Dexmeditomedine given intrathecally along with Bupivacaine produce significantly longer duration of sensory and motor block than Bupivacaine alone without serious side effects less Hypotension and Bradycardia compare to Bupivacaine. It maintains patient arousability and respiratory function. Bupivacaine: is a synthetic local anesthetic drug and it belongs to Amide group, $\mathrm{Pka}=8.1 \mathrm{ph} 0.5 \%$ bupivacaine is 5.5 specific gravity of 1.0227 - 1.0278. protein binding $95 \%$ its volume of distribution is $73 \mathrm{~L}$ and clearance is $0.47 \mathrm{tt} / \mathrm{min}$. Elimination halflife is 210 minutes. Bupivacaine act as a conduction blocker of nerve impulses by sodium pump inhibition. More specifically bupivacaine is classified as pipecoloxylides.

\section{Materials and Methods}

This prospective comparative study was conducted after obtaining institutional Ethics Committee approval and written informed consent. The person giving the drug and the monitoring personnel were blinded 60 adult patients of ASA grade I and II aged between $20-$ 50 year. Undergoing various elective lower limb (Orthopaedics) surgeries. Patient were randomly allocated to one of the two group of 30 each according to computer generated randomized table satisfying inclusion and exclusion criteria's.

\section{Inclusion Criteria}

- ASA-I/II

- Age group between 20 - 50

- Height- $155-175 \mathrm{~cm}$

\section{Exclusion Criteria}

- History of allergy to local anaesthetics.

- Patients with spinal deformities, peripheral neuropathy, bleeding disorders or anticoagulation therapy.

- Patients with serious systemic illness, psychiatric illness, mental retardation. Patients with Diabetes mellitus, systemic Hypertension and Ischaemic heart disease,

Patients satisfying the selection criteria were randomly divided into two groups of 30 each as per the random number chart. Both the patient and the principal investigator were blinded for the drug, which was being administered during the period of observation and the drug being prepared by a qualified assistant.

\section{Monitors}

- Non-invasive Blood pressure monitoring

- Pulse oximeter

- ECG

- Visual assessment of respiration

\section{Interventions}

Preparation: All the patients were selected after pre-op evaluation and written informed consent from all the patients. Psychological preparation was done and the procedure explained to all the patients in advance.

On the table: An IV access was secured using an $18 \mathrm{G}$ cannula under local anesthesia in the left forearm vein and an isotonic saline drip was started at a rate of $8 \mathrm{ml} / \mathrm{kg} / \mathrm{hr}$. Monitors including a pulse oxymeter, B.P apparatus \& an ECG monitor were routinely used. Midazolam was titrated with increments of $0.25 \mathrm{mg}$ each and used up to a maximum dose of $0.025 \mathrm{mg} / \mathrm{kg}$ to have sufficient anxiolysis without producing too much sedation. The patient was kept left lateral and positioned for a subarachnoid block. Under strict aseptic precautions after giving local anaesthesia with a $26 \mathrm{G}$ needle, lumbar puncture was done with a Quinke needle of $23 \mathrm{G}$ size using either the midline or paramedian approach in the $\mathrm{L} 3 / 4$ or $\mathrm{L}$ $2 / 3$ space. After clear CSF was flowing freely, (the Dexmeditomedine group received $5 \mu \mathrm{g}(0.5)$ cc of Dexmeditomedine with $0.5 \% 2$ cc $(10 \mathrm{mg})$ hyperbaric bupivacaine and the Bupavacaine group who received of $0.5 \% 2.5 \mathrm{cc}$ of hyperbaric bupivacaine) was injected into the subarachnoid space. The table was kept horizontal throughout. The patient was turned supine immediately. Throughout the procedure patient received an oxygen supplementation of $4 \mathrm{~L} /$ minute via a simple oxygen mask.

\section{Main outcome and measurements}

To measure the haemodyanamic changes like 
changes in pulse rate and blood pressure and other side effects like nausea, vomiting, sedation, shivering and pruritis in the group with Dexmeditomedine-Bupivacaine group and Bupivacaine group alone.

Data Collection: The principal investigator himself collected the data. Pulse rate and blood pressure were checked every minute for the first 20 minutes and every two-minute for the next 20 minutes and every five minutes till the end of surgery and then every 10-15 minutes for three hours post operatively. They were followed up for 24 hours thereafter with routine post-op care hi the post-surgical wards.

Complications during surgery were treated as follows: Hypotension (defined as a systolic blood pressure of $<100 \mathrm{~mm} \mathrm{Hg}$ or fall of $30 \%$ or more of initial reading, whichever was higher) was treated with $6 \mathrm{mg}$ increments of iv ephedrine and $200 \mathrm{ml}$ normal saline. Bradycardia (defined as a heart rate $<50 \mathrm{bpm}$ ) was treated with iv atropine $0.3-0.5 \mathrm{mg}$, if it was associated with hypotension.

\section{Observations and Results}

The observations made were tabulated and analysed using appropriate statistical tools. The patients in both Dexmeditomedine group \& the Bupivacaine group were comparable with respect to their age, height and duration of surgery (unpaired t test)

\begin{tabular}{|c|c|c|c|c|c|c|}
\hline Parameter & Group & Mean & \pm SD & t value & $\begin{array}{c}P \\
\text { value }\end{array}$ & Comments \\
\hline Age (yrs) & Dex & 42.53 & 5.64 & \multirow[b]{2}{*}{0.959} & \multirow[b]{2}{*}{$\stackrel{>}{0.05}$} & \multirow{2}{*}{$\begin{array}{c}\text { Not } \\
\text { significant }\end{array}$} \\
\hline & $\begin{array}{c}\text { bupivacin } \\
\mathrm{e}\end{array}$ & 41.17 & 5.40 & & & \\
\hline \multirow[t]{2}{*}{ Height $(\mathrm{cm})$} & Dexmee & 168.07 & 4.21 & \multirow[b]{2}{*}{-0.059} & \multirow[b]{2}{*}{$\stackrel{>}{0.05}$} & \multirow[b]{2}{*}{$\begin{array}{c}\text { Not } \\
\text { significant }\end{array}$} \\
\hline & $\begin{array}{c}\text { bupivacin } \\
\mathrm{e}\end{array}$ & 168.13 & 4.49 & & & \\
\hline \multirow{2}{*}{$\begin{array}{l}\text { Duration of } \\
\text { Surgery (min) }\end{array}$} & Dexme & 61.73 & 10.88 & \multirow[b]{2}{*}{0.835} & \multirow[b]{2}{*}{$\stackrel{>}{0.05}$} & \multirow{2}{*}{$\begin{array}{c}\text { Not } \\
\text { significant }\end{array}$} \\
\hline & $\begin{array}{c}\text { bupivacin } \\
\mathrm{e}\end{array}$ & 59.37 & 11.08 & & & \\
\hline
\end{tabular}

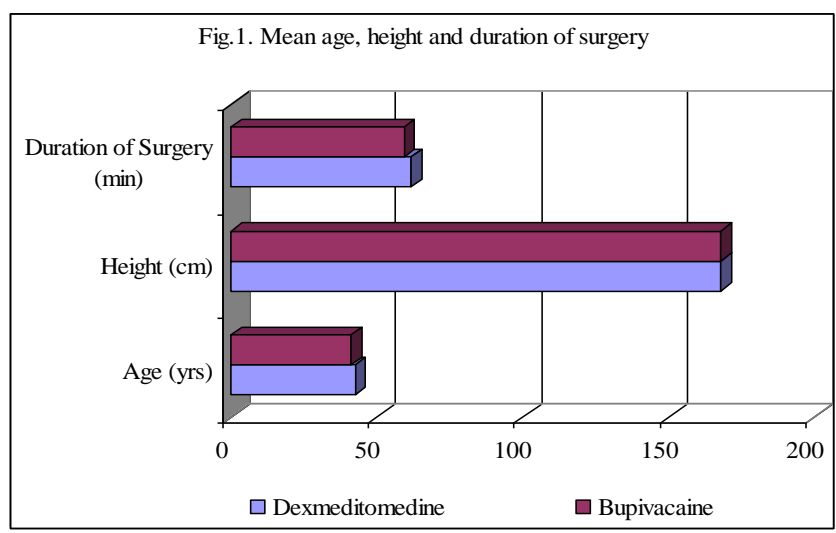

\section{Haemodynamic Changes}

Pulse rate \& blood pressure were checked every minute for the first 20 minutes and every two minute for the next 10 minute for the next 10 minutes and every five minutes till the end of surgery and then every 10-15 minutes for three hours post operatively. They were followed up to 24 hours thereafter with routine post-op care in the post-surgical wards.

Hypotension and Bradycardia: While analyzing the two parameters - pulse rate $\&$ blood pressure, we included the data of only the first 30 minutes of these variables for out statistical analysis because it is the period during which the intrathecal drug usually gets fixed and exerts its significant sympatholytic effect. Only two subjects among the Dexmeditomedine group had episodes of hypotension that required vasopressors, whereas 16 among the Bupivacaine group had incidence of hypotension in the first 30 minutes after administering the subarachnoid block. Moreover 9 among these 16 subjects, among Bupivacaine group, had persistence of hypotension that required more than two boluses of the vasopressor (VSP), while none among the Dexmeditomedine group required that.
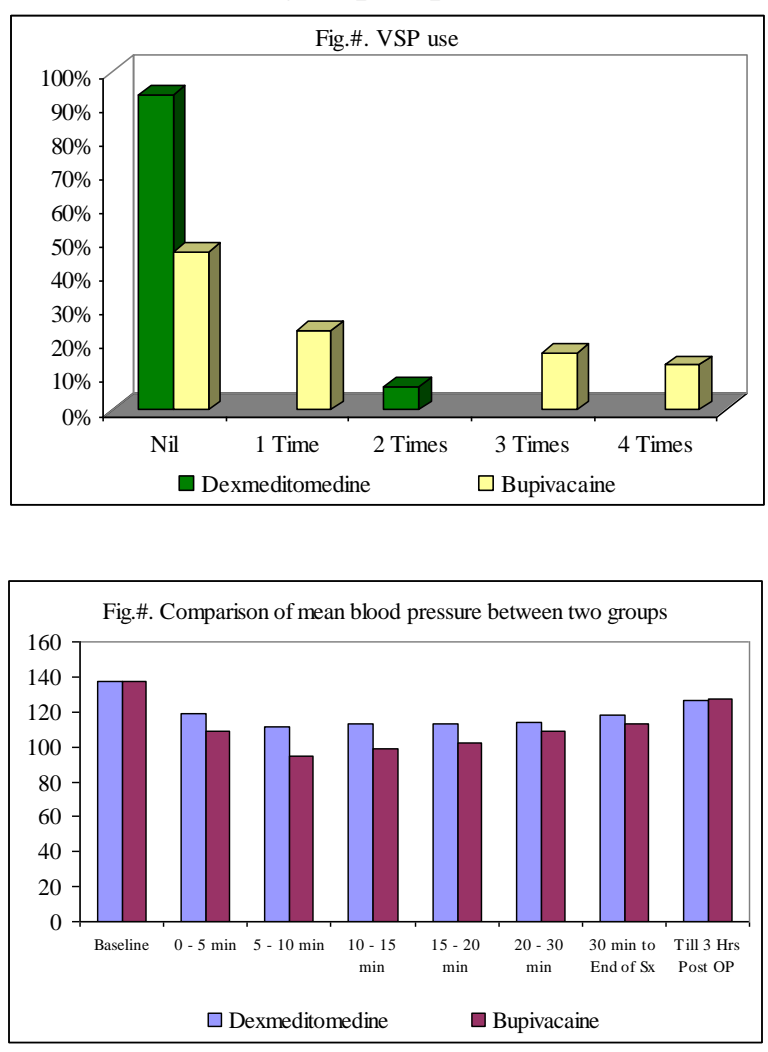


\begin{tabular}{|c|c|c|c|c|c|c|c|c|c|}
\hline & $\mathbf{N}$ & Minimum & Maximum & Mean & $95 \%$ CI & Median & $95 \%$ CI & SD & Normal Distr. \\
\hline B.P_Base_line & 60 & 1.220 & 164.000 & 135.520 & $\begin{array}{c}130.121 \text { to } \\
140.919\end{array}$ & 140.000 & $\begin{array}{c}135.878 \text { to } \\
144.000\end{array}$ & 20.9000 & $<0.0001$ \\
\hline $\begin{array}{c}\text { B.P_Base_line } \\
\text { _0_5_mt }\end{array}$ & 60 & 86.000 & 180.000 & 113.667 & $\begin{array}{c}109.596 \text { to } \\
117.737\end{array}$ & 110.000 & $\begin{array}{c}108.000 \text { to } \\
120.000\end{array}$ & 15.7573 & 0.0005 \\
\hline $\begin{array}{l}\text { B.P_Base_line } \\
\text { _5__10_mt }\end{array}$ & 59 & 18.000 & 136.000 & 102.746 & $\begin{array}{c}98.059 \text { to } \\
107.432 \\
\end{array}$ & 106.000 & $\begin{array}{c}96.000 \text { to } \\
110.000\end{array}$ & 17.9843 & $<0.0001$ \\
\hline $\begin{array}{c}\text { B.P_Base_line } \\
\text { _10_15_mt }\end{array}$ & 57 & 70.000 & 146.000 & 105.579 & $\begin{array}{c}101.790 \text { to } \\
109.368\end{array}$ & 106.000 & $\begin{array}{c}100.000 \text { to } \\
110.736\end{array}$ & 14.2815 & 0.6428 \\
\hline $\begin{array}{l}\text { B.P_Base_line } \\
\text { _15_20_mt }\end{array}$ & 57 & 76.000 & 160.000 & 107.684 & $\begin{array}{c}103.699 \text { to } \\
111.669\end{array}$ & 110.000 & $\begin{array}{c}105.264 \text { to } \\
110.736\end{array}$ & 15.0180 & 0.0021 \\
\hline $\begin{array}{cc} \\
\text { B.P_Base_line } \\
20 \_30 \_\mathrm{mt}\end{array}$ & 59 & 84.000 & 152.000 & 111.576 & $\begin{array}{c}108.341 \text { to } \\
114.811\end{array}$ & 110.000 & $\begin{array}{c}107.006 \text { to } \\
114.000\end{array}$ & 12.4141 & 0.0006 \\
\hline $\begin{array}{l}\text { B.P_Base_line } \\
\text { _30_end_of_s } \\
\text { urgery }\end{array}$ & 53 & 94.000 & 160.000 & 116.528 & $\begin{array}{c}112.907 \text { to } \\
120.150\end{array}$ & 114.000 & $\begin{array}{c}110.000 \text { to } \\
118.000\end{array}$ & 13.1392 & 0.0002 \\
\hline $\begin{array}{l}\text { B.P_Base_line } \\
\text { _Till_3_h_pos } \\
\text { t_op }\end{array}$ & 59 & 100.000 & 170.000 & 127.085 & $\begin{array}{c}123.332 \text { to } \\
130.837\end{array}$ & 128.000 & $\begin{array}{c}120.000 \text { to } \\
130.000\end{array}$ & 14.3998 & 0.0543 \\
\hline
\end{tabular}

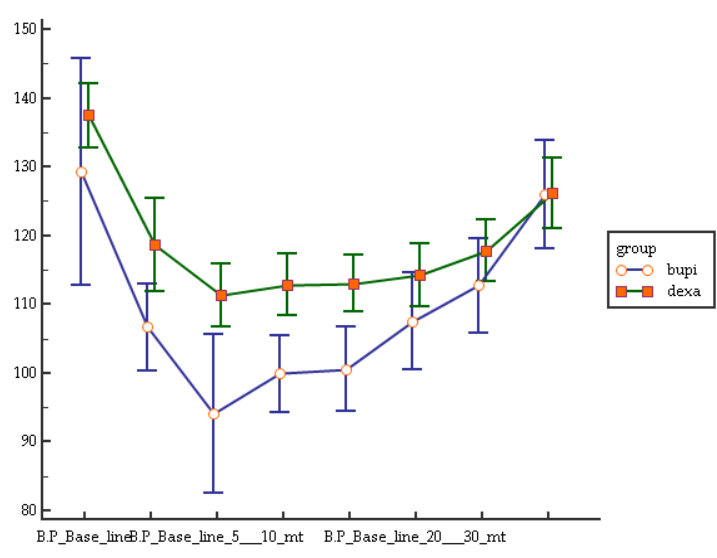

\begin{tabular}{|l|l|l|l|l|l|l|}
\hline $\begin{array}{l}\text { Paramet } \\
\text { er }\end{array}$ & Group & Mean & \pm SD & $\begin{array}{l}\mathbf{t} \\
\text { value }\end{array}$ & $\begin{array}{l}\text { P } \\
\text { value }\end{array}$ & $\begin{array}{l}\text { Comm } \\
\text { ents }\end{array}$ \\
\hline $\begin{array}{l}\text { Vasopre } \\
\text { ssor use }\end{array}$ & $\begin{array}{l}\text { exmeditomedin } \\
\text { e }\end{array}$ & 0.13 & 0.51 & -3.851 & $<$ & $\begin{array}{l}\text { Clinica } \\
\text { lly } \\
\text { Signifi } \\
\text { cant }\end{array}$ \\
\cline { 2 - 4 }
\end{tabular}

The most significant side effects reported about the use of intrathecal $\alpha 2$ - adrenoreceptor agonists are bradycardia and Hypotension. In present study hypotension Bradycardia was more in the Bupivacane group than in the Dexmeditomedine group.

\section{Comparison of Pulse Rate between two groups}

\begin{tabular}{|c|c|c|c|c|c|c|c|c|}
\hline & $\begin{array}{l}\text { PR_Ba } \\
\text { se_line }\end{array}$ & $\begin{array}{c}\text { PR_Base_line } \\
\text { 0_5_mt }\end{array}$ & $\begin{array}{l}\text { PR_Base_lin } \\
\text { e_5_10_mt }\end{array}$ & $\begin{array}{c}\text { PR_Base_line_10 } \\
15 \_\mathrm{mt}\end{array}$ & $\begin{array}{c}\text { PR_Base_line_1 } \\
5 \_20 \_\mathrm{mt}\end{array}$ & $\begin{array}{c}\text { PR_Base_line_2 } \\
0 \_30 \_\mathrm{mt}\end{array}$ & $\begin{array}{c}\text { PR_Base_line_30_e } \\
\text { nd_of_surgery }\end{array}$ & $\begin{array}{c}\text { PR_Base_line_Till_ } \\
\text { 3_h_post_op }\end{array}$ \\
\hline $\mathrm{N}$ & 60 & 60 & 60 & 60 & 60 & 60 & 60 & 60 \\
\hline Minimum & 56.000 & 49.000 & 56.000 & 54.000 & 56.000 & 56.000 & 58.000 & 0.600 \\
\hline Maximum & 94.000 & 90.000 & 96.000 & 88.000 & 88.000 & 88.000 & 92.000 & 88.000 \\
\hline Mean & 70.667 & 68.333 & 68.467 & 70.267 & 70.683 & 71.083 & 70.850 & 69.660 \\
\hline $95 \% \mathrm{CI}$ & $\begin{array}{c}68.457 \\
\text { to } \\
72.876\end{array}$ & $\begin{array}{c}65.883 \text { to } \\
70.784\end{array}$ & $\begin{array}{c}65.971 \text { to } \\
70.962\end{array}$ & 67.965 to 72.569 & 68.421 to 72.946 & 68.990 to 73.176 & 68.726 to 72.974 & 66.475 to 72.845 \\
\hline Median & 70.000 & 68.000 & 68.000 & 69.000 & 69.000 & 70.500 & 70.000 & 69.000 \\
\hline $95 \% \mathrm{CI}$ & $\begin{array}{c}68.000 \\
\text { to } \\
74.000\end{array}$ & $\begin{array}{c}64.000 \text { to } \\
70.000\end{array}$ & $\begin{array}{c}62.000 \text { to } \\
70.000\end{array}$ & 66.000 to 76.000 & 66.000 to 72.000 & 67.878 to 72.000 & 66.000 to 74.000 & 66.939 to 74.000 \\
\hline SD & 8.5542 & 9.4862 & 9.6612 & 8.9117 & 8.7575 & 8.1017 & 8.2211 & 12.3291 \\
\hline $\begin{array}{l}\text { Normal } \\
\text { Distr. }\end{array}$ & 0.1415 & 0.2557 & 0.0008 & 0.0164 & 0.0035 & 0.0362 & 0.0437 & $<0.0001$ \\
\hline
\end{tabular}
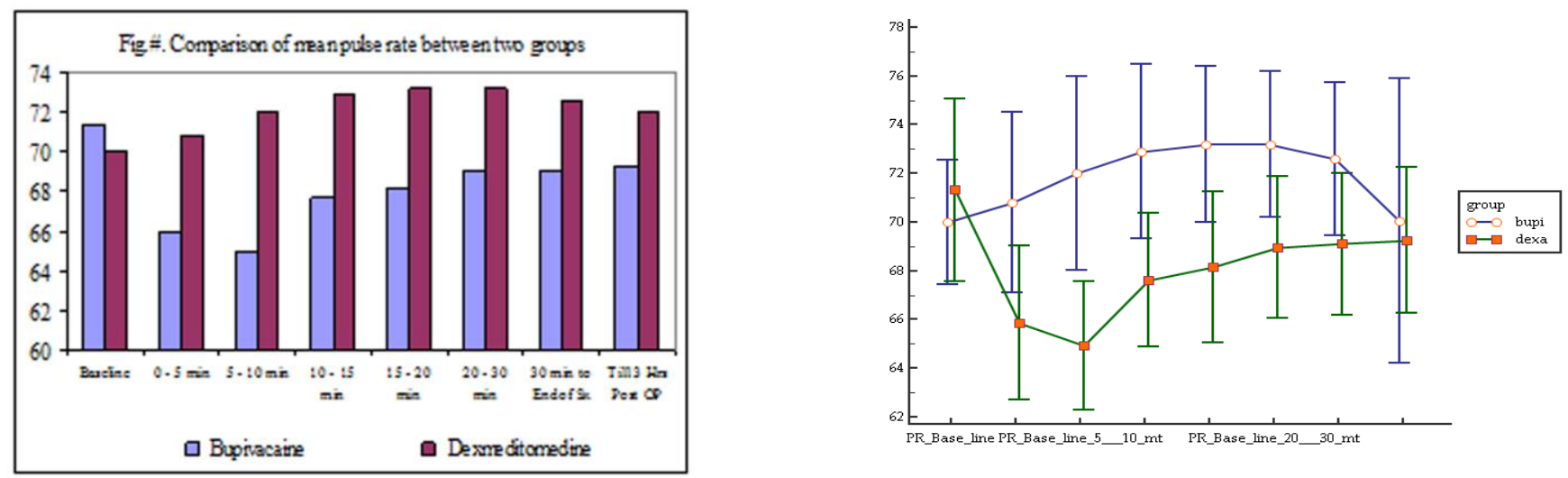
Summary statistics table

\begin{tabular}{|c|c|c|c|c|c|c|c|c|c|}
\hline & $\mathrm{N}$ & Minimum & Maximum & Mean & $95 \% \mathrm{CI}$ & Median & $95 \% \mathrm{CI}$ & SD & Normal Distr. \\
\hline PR_Base_line & 60 & 56.000 & 94.000 & 70.667 & 68.457 to 72.876 & 70.000 & 68.000 to 74.000 & 8.5542 & 0.1415 \\
\hline PR_Base_line_0_5_mt & 60 & 49.000 & 90.000 & 68.333 & 65.883 to 70.784 & 68.000 & 64.000 to 70.000 & 9.4862 & 0.2557 \\
\hline PR_Base_line_5__10_mt & 60 & 56.000 & 96.000 & 68.467 & 65.971 to 70.962 & 68.000 & 62.000 to 70.000 & 9.6612 & 0.0008 \\
\hline PR_Base_line_10 $15 \mathrm{mt}$ & 60 & 54.000 & 88.000 & 70.267 & 67.965 to 72.569 & 69.000 & 66.000 to 76.000 & 8.9117 & 0.0164 \\
\hline PR_Base_line_15_20_mt & 60 & 56.000 & 88.000 & 70.683 & 68.421 to 72.946 & 69.000 & 66.000 to 72.000 & 8.7575 & 0.0035 \\
\hline PR_Base_line_20_30_mt & 60 & 56.000 & 88.000 & 71.083 & 68.990 to 73.176 & 70.500 & 67.878 to 72.000 & 8.1017 & 0.0362 \\
\hline PR_Base_line_30_end_of_surgery & 60 & 58.000 & 92.000 & 70.850 & 68.726 to 72.974 & 70.000 & 66.000 to 74.000 & 8.2211 & 0.0437 \\
\hline PR_Base_line_Till_3_h_post_op & 60 & 0.600 & 88.000 & 69.660 & 66.475 to 72.845 & 69.000 & 66.939 to 74.000 & 12.3291 & $<0.0001$ \\
\hline
\end{tabular}

\section{Other Side Effects}

No subjects among either group had any incidence of sedation or respiratory depression or pruritis. 2 subjects from Bupivacaine group had intra operative nausea and vomiting, while only one subject among the Dexmeditomedine group had it. The incidence of shivering was higher among the Bupivacaine group with 9 subjects experienced shivering, while none had in Dexmeditomedine group.

\section{Discussion}

Here we discuss the Haemodynamic changes like blood pressure and pulse rate these parameters checked the every 5 minutes till the end of surgery and every $10-15$ minutes for three hours post operatively. The result of the study shows that the supplementation of lower dose of Bupivacaine with $5 \mu \mathrm{g}$ Dexmeditomedine significantly ${ }^{1-5}$ prolonged sensory block and less hypotension and bradycardia compared with intrathecal Bupivacaine alone. Intrathecal bupivacaine group alone significantly reduces blood pressure and heart rate from this study.

The American Journal of applied sciences, Publication effect of adding Dexmedetomedine versus Fentanyl to Intrathecal Bupavacine on spinal block in Gynaecological procedures, the purpose of this study was evaluated the onset and duration of sensory and block as well as operative analgesia and Haemodynamic changes of Dexmeditomedine or fentanyl given intrathecally with plain $0.5 \%$ Bupivacaine for spinal anaesthesia. Patient were randomly allocated to receive either $10 \mathrm{mg}$ isobasic bupivacaine plus 5 $\mu \mathrm{g}$ dexmedetomedine (group $\mathrm{D} \mathrm{n}=38$ ) or $10 \mathrm{mg}$ isobaric bupicaine plus $25 \mathrm{mg}$ fentanyl (group Fn $=38$ ), results patients in group D had significant longer sensory and motor block and less hypotension and bradycardia than patients in group F. The bupivacaine group had more hypotensionand bradycardia than Dexmeditomedine group.

In the present study and based on the above study's findings Dexmeditomedine in a dose of $5 \mu \mathrm{g}$ was used for supplementation spinal Bupivacaine, showed the duration of sensory block in (Dexmeditomedine) group is $295+40 \mathrm{~min}$ and bupivacaine group $219 \pm 15(\mathrm{P}<0.001)$ and it is highly significant. Dexmeditomedine is a highly selective $\alpha 2$ adrenoreceptor agonist approved as intravenous sedative and adjuvant to anesthesia. Dexmeditomedine when used intravenously during anesthesia reduces opioid and Inhalatonal anesthetics requirements. Compared with clonidine a $\alpha 2$ adrenoreceptor agonist, the affinity of Dexmeditomedine to $\alpha 2$ receptors has been reported to be 10 times more than clonidine. Moreover, Kalso et al. and post et al. reported a 1:10 dose ratio between intrathecal Dexmeditomedine and clonidine in animals. Clinical studies in surgical patients showed that intrathecal clonidine increases the duration of sensory block when added to spinal local anesthetics and this effect of clonidine in dose dependent. From Kanazi study and animal studies, we assumed that 3 - $5 \mu \mathrm{g}$ Dexmeditomedine would be equipotent to $30-45 \mu \mathrm{g}$ clonidine when used for supplementation of spinal Bupivacaine.

In this study intrathecal Dexmeditomedine and Bupivacaine block has resulted in significantly less side effects like hypotension and bradycardia than intrathecal Bupivacaine alone. The most significant side effects reported about the use of intrathecal $\alpha 2$ adrenoreceptor agonist are bradycardia and hypotension, in present study 
these side effects were not significant probably because we used small dose of intrathecal Dexmeditomedine, which was confirmed by the findings of Kanazi report. In present study hypotension and bradycardia was more in the Bupivacaine group than in the Dexmeditomedine group.

\section{Conclusion}

After analyzing the results our study, Dexmeditomedine group is associated lessor incidence of Hypotension and bradycardia, lessor degree of motor blockade and improved analgesic efficacy. Intrathecal Dexmeditomedine supplementation of spinal block seems to be less haemodynamic changes and a good alternative to intrathecal fentanyl. However, Intrathecal dose of Dexmeditomedine to hyperbaric bupivacaine, use in present study needs further clinical studies to prove its efficacy and safety and sample size is adequate randomization not done and recommends further clinical evaluation.

In conclusion, $5 \mu \mathrm{g}$ Dexmeditomedine seems to be an attractive alternative as adjuvant to spinal bupivacaine in surgical procedures especially in those that need quite long time with minimal side effects like less hypotension bradycardia and excellent quality of spinal analgesia compared to hyperbaric Bupivacaine alone. In this study we concluded that Hyperbaric Bupivacaine group had more incidence of hypotension and bradycardia compared to Dexmeditomedine group.

\section{Financial support and sponsorship: Nil}

Conflicts of Interest: There are no conflicts of Interest

\section{References}

1. The effect of intrathecal Dexmeditomedine in spinal anaesthesia using low dose hyperbaric Bupivacaine for TURP in elderly.

2. A comparative study of Intrathecal Dexmeditomedine and fentanyl as adjuvant to Bupivacaine - Journal of
Anaesthesiology clinical Pharmacology :2011 July -Sept 27; 339-343.

3. Intrathecal fentanyl prologs Sonsory Bupavacaine spinal block - Cand J. Anesthesia - 1995.

4. G.E. Kanazi, M.T.Aouad, S.I.Jabbour Khoury, M.D.AI Jazzer, M.M. Alameddine, R. A1-Yaman, M. Bulbul and A.S. Baraka. Effect of low-dose dexmedetomidine or clonidine on the characteristics of bupivacaine spinal block. Acia Anesthesiol Scnad 2006; 50: 227 117. DOI 10.1111/j.1399-65762006.00919.x

5. Van de velde 2006 CSEB for cs. Dose depondent effects of Hypocardia bupivacaine in maternal Haemodynamics - Hypotension an important side effect of SA.- AnasthAnalg

6. Gudaityte - 2009 low dose spinal Hypocardia Bupivacaine for anorectal surgery: a double- blinded, reandomised controlled study - J Clin Anaesthesia.

7. Van Tuijl 2008.Intrathecal Low dose Hyperbaric bupivacaine - Clonidine combination in outpatient knee Arthroscopy: a randomized control trial Acta Anaesthesiol Scand.

8. Comparison of Intrathecal Dexmeditomedine and fentanyl as adjuvant to Hypobaric Bupivacaine in SAB for Lower limb orthopedic surgeries. Routray 2017. (Anaesthesia Essays Res).

9. Gupta R, Verma R, Bogra J, Kohili M, Rama R, Khushwaha JK, - A comparative study of Intrathecal dexmeditomedine and fentanyl as adjuvant to Bupivacaine. Journal Anaesthsiology and Clinical Pharmacology 2011; 27: 339-343.

10. Effect of low dose of Dexmeditomedine and clonidine on the characteristics of Bupivacaine (Acta Anaesthesiology Scand 2006).

11. Efficacy of intrathecally administered Dexmeditomedine versus with fentanyl in 
patient undergoing Major abdominal cancer surgery - from : South Egypt Cancer Institute, Anaesthesia Intensive Care and Pain Management Department, Assiut Egypt. 